\title{
Personal health information in verse
}

\section{Section Editor}

Anne W. McCammon,

MD, FAAN

Nina F. Schor, MD, PhD

Correspondence to

Dr. Schor:

Nina_Schor@urmc.rochester.edu
WHAT MUST IT SAY ABOUT ME?

What must it say about me

That my poetry is published in

Neurology?

I suppose it is better than if my

Science

Were published in

The Yale Review.

What must it say about me

That even those of my patients with

Signs of their symptoms

Have complaints unaccompanied by

Reason

Or relevant signs

Of disease?

What must it say about me

That mistakes of importance to patients long gone Inform

And live on in survival of others they never will Know?
HIPAA

So many of the things that move us Are a secret these days.

A secret from the estranged wife, From the loving husband,

From the divorced parent who has been thrown out of the house.

A secret the patient keeps from himself when he looks in the mirror in the morning.

(It is no wonder we doctors resort to poetry.) 


\section{Neurology}

\section{Personal health information in verse}

Nina F. Schor

Neurology 2013;81;e123

DOI 10.1212/WNL.0b013e3182a958a9

This information is current as of October 21, 2013

\section{Updated Information \& Services}

\section{Subspecialty Collections}

Permissions \& Licensing

Reprints including high resolution figures, can be found at: http://n.neurology.org/content/81/17/e123.full

This article, along with others on similar topics, appears in the following collection(s):

All Clinical Neurology

http://n.neurology.org/cgi/collection/all_clinical_neurology Patient safety

http://n.neurology.org/cgi/collection/patient_safety

Professional conduct and ethics

http://n.neurology.org/cgi/collection/professional_conduct_and_ethics

Information about reproducing this article in parts (figures,tables) or in its entirety can be found online at:

http://www.neurology.org/about/about_the_journal\#permissions

Information about ordering reprints can be found online:

http://n.neurology.org/subscribers/advertise

Neurology ${ }^{\circledR}$ is the official journal of the American Academy of Neurology. Published continuously since 1951, it is now a weekly with 48 issues per year. Copyright @ 2013 American Academy of Neurology. All rights reserved. Print ISSN: 0028-3878. Online ISSN: 1526-632X.

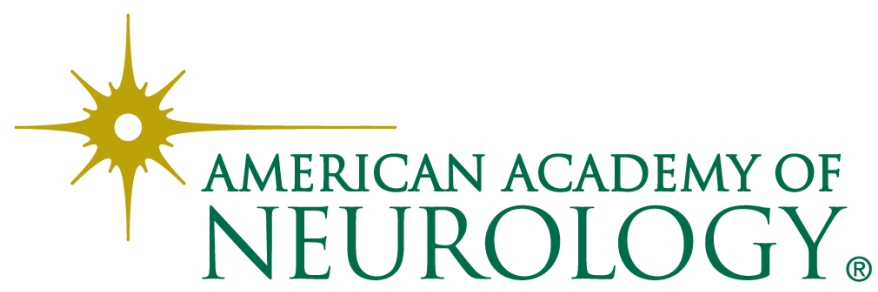

